\title{
How soon can I Get Blood, Doctor? Dual Red Cell Alloimmunisation in an Adult Male
}

Sangeeta Pahuja, Daljit Kaur ${ }^{\star}$, Manjula Jain and Reeta Rai

Department of Transfusion Medicine, Max Superspeciality Hospital, Dehradun, India

*Corresponding author: Daljit Kaur, Department of Transfusion Medicine, Max Superspeciality Hospital, Dehradun-248001, India, Tel: 91 8826788911; E-mail: drdaljit@outlook.com

Received date: Apr 20, 2015, Accepted date: May 12, 2015, Publication date: May 18, 2015

Copyright: () 2015 Pahuja S, et al. This is an open-access article distributed under the terms of the Creative Commons Attribution License, which permits unrestricted use, distribution, and reproduction in any medium, provided the original author and source are credited.

\begin{abstract}
The advent of transfusion medicine alongwith the escalating trend of blood and blood components usage have certainly established newer ways to act in the exigencies. Maintaing an inventory for phenotyped donor red cells at a blood center round the clock, shortens the turn around time for compatibility testing for antibody to a high prevalence antigen.The present case report focusses on the need for donor red cell phenotyping for all the donated blood units at a blood center.
\end{abstract}

Keywords: Donor red cell phenotyping; Antibody; Rh blood group system

\section{Introduction}

$\mathrm{Rh}$ antibodies result from exposure of the individual's immune system to foreign human red cells, either through transfusion or pregnancy. Rh antigens are highly immunogenic, $\mathrm{D}$ being the most potent antigen followed by $\mathrm{c}, \mathrm{E}, \mathrm{C}$ and $\mathrm{e}$ [1]. A huge data on alloimmunisation to D as well as to other antigens like c, $\mathrm{C}$ and $\mathrm{E}$ of $\mathrm{Rh}$ blood group system exist but alloimmunisation to anti-e has rarely been reported. Here we report a case of incidental detection of formation of anti-e along with underlying anti- $\mathrm{C}$ in an adult male with anemia.

\section{Case Report}

A 40 year old male was admitted in emergency with fever, ascites, diarrhea and severe anemia with hemoglobin $3.1 \mathrm{gm} \%$. The patient had history of transfusion of two units of blood during his previous hospitalisation in other city hospital 2 years back. On receipt of blood transfusion request, he was found to be $\mathrm{AB} \mathrm{Rh} \mathrm{D}$ positive. Emergency crossmatch results revealed incompatibility ( $3+$ to $4+$ agglutination with LISS/Coomb gel card, Biorad) with $9 \mathrm{AB}$ positive blood units. Extended immunohaematological work up was performed to find any unexpected antibody causing incompatibility. Three cell antibody screen panel (ID-Diacell I-II-III, Biorad, Japan) showed 3+ agglutination reaction in screening cell I and $2+$ in SC-III indicating possibilities of anti-C, e, $\mathrm{Kp}^{\mathrm{a}}, \mathrm{Jk}^{\mathrm{b}}$ and $\mathrm{Le}^{\mathrm{a}}$. Further 11 cell antibody identification panel (ID-DiaPanel, Biorad, Japan) showed negative reaction with cell 3 and positive reaction of varying strength with all other cells with autocontrol being negative. The results confirmed presence of anti-e with strong possibility of anti-C in patient's serum. The patient's red cells were phenotyped for ' $e$ ' and ' $C$ ' antigen and was found to be negative further confirming both the implicated alloantibodies in his serum.

Although routinely we are performing extended Rh and Kell red cell phenotyping of the entire donor units. But due to delay in supply of red cell phenotyping gel cards during the period of index patient hospitalization, we could not phenotype donor red cells for a week by gel cards. Therefore tube technique, a time consuming method was used for the same. According to the then present inventory, $10 \mathrm{AB}$ positive blood units were typed but none of them was found to be ' $\mathrm{e}$ ' antigen negative. Since, $A B$ positive is universal recipient for red cell transfusion, switching to next compatible available blood group was done and typing $60 \mathrm{~B}$ positive units also did not give us any 'e' negative unit. Five A positive phenotyped units were also 'e' positive. Finally, after typing 75 units, we selected one $\mathrm{O}$ positive unit with phenotype ccEE from our Rh profile inventory which was already phenotyped earlier according to our routine protocol. This unit was crossmatch (AHG phase) compatible with patient's serum. An immunohematological report was issued indicating presence of dual alloantibodies (anti-e and anti-C) in patient's serum with suggestion to always carry this report along.

Simultanoeusly, other hematological investigations revealed that the patient had megaloblastic anemia and he was put on Vitamin B12 and folic acid. His hemoglobin rose to $6.5 \mathrm{gm} \%$ and was deferred for blood transfusion in this hospital stay. $\mathrm{He}$ was provided with an immunohematological report indicating that his serum contains antibodies to ' $\mathrm{e}$ ' and ' $\mathrm{C}$ ' antigen.

\section{Discussion}

Unlike other antigens of Rh blood group system, the formation of anti-e is rarely reported [2]. Various studies reporting alloimmunisation in large number of multiply transfused thalassaemia patients also did not report any patient with anti-e as implicating alloantibody $[3,4]$. The frequency of $\mathrm{Rh}$ antigens in north Indian population is reported to be ' $\mathrm{e}$ ' the most common (99\%), followed by D (93\%), C (85.1\%), c (62.3\%), and E (21.5\%) [5]. This shows that only $1 \%$ of the population lacks 'e' antigen and has the potential to develop alloimmunisation through pregnancy or transfusion. Also the frequency of $\mathrm{R}_{2} \mathrm{R}_{2}$ (ccEE) phenotype in Indian population is very low $(0.8 \%)$ as reported by Makroo et al. [6]. However, it is already mentioned that the ' $\mathrm{e}$ ' antigen is the least potent of all $\mathrm{Rh}$ antigens 
Citation: Pahuja S, Kaur D, Jain M, Rai R (2015) How soon can I Get Blood, Doctor? Dual Red Cell Alloimmunisation in an Adult Male. J Blood

Page 2 of 2

followed by anti-C and therefore the anemia or HDN that occurs due to red cell destruction is also mild [7].

\section{Conclusion}

Taking into account the high prevalence of 'e' antigen (98-99\%), it becomes really cumbersome to find an antigen negative red cell unit in emergency. Red cell phenotyping of blood donors is not a routine practice in our resource constrained country, but every effort should be made to put such system in place in all the blood centres. This will enhance the availability of rare blood units round the clock without any undue delay. Establishing good networking between all the public blood centres for provision of antigen negative bag in case of exigencies will bring in high efficiency in transfusion services and hence more satisfaction among patient population.

\section{References}

1. Harmening DM (2005) Modern blood banking and transfusion practices (5th edn), FA Davis Company, Philadelphia, United States of America: 142.
2. McAdams RM, Dotzler SA, Winter LW, Kerecman JD (2008) Severe hemolytic disease of the newborn from anti-e. Journal of Perinatology 28: 230-232.

3. Dhawan HK, Kumawat V, Marwaha N, Sharma RR, Sachdev S, et al. (2014) Alloimmunization and autoimmunization in transfusion dependent thalassemia major patients. Study on 319 patients. Asian Journal of Transfusion Science 8: 84-88.

4. Pahuja S, Pujani M, Gupta KS, Chandra J, Jain M (2010) Alloimmunization and red cell autoimmunization in multi transfused thalassemics of Indian origin. Hematology 15: 174-177.

5. http://www.hindawi.com/journals/ah/2013/215454/.

6. Makroo RN, Bhatia A, Gupta R, Phillip J (2013) Prevalence of Rh, Duffy, Kell, Kidd \& MNSs blood group antigens in the Indian blood donor population. The Indian Journal of Medical Research 137: 521-526.

7. Roback JD (2011) AABB Technical Manual 17th Edition. Bethesda, Maryland; AABB Press, 405. 